\title{
Pemberdayaan Masyarakat Pemulung Sampah Sungai Citarum Melalui Koperasi Bangkit Bersama
}

\author{
Friska Indria Nora Harahap \\ Pendidikan Luar Sekolah, Universitas Pendidikan Indonesia. Jalan Dr. Setiabudhi No. 229, \\ Isola, Kota Bandung, Jawa Barat 40154, Indonesia \\ Email: hrp.frischa@gmail.com \\ Received: 11 August 2017; Revised: 13 December 2017; Accepted: 20 December 2017
}

\begin{abstract}
Abstrak
Penelitian ini bertujuan untuk menganalisis bentuk pemberdayaan masyarakat yang dilakukan melalui Koperasi Bangkit Bersama dengan menggunakan pendekatan kualitatif dan metode wawancara secara mendalam kepada 5 informan yang terlibat langsung, dianggap memahami dan dapat memberikan informasi secara benar yang berkaitan dengan fokus penelitian yang dilakukan. Temuan dari penelitian ini menunjukkan bahwa masyarakat merasakan kesejahteraan baik secara ekonomi dan kelestarian lingkungan sekitar dikarenakan volume sampah yang semakin berkurang, dan ekosistem air yang lambat laun akan membaik dikarenakan eceng gondok yang dimanfaatkan oleh masyarakat. Bentuk pemberdayaan yang dilakukan dengan cara menumbuhkan kesadaran dan memberikan pelatihan agar masyarakat mempunyai keterampilan untuk mengolah potensi yang mereka miliki dan bisa mengatasi permasalah yang mereka hadapi.
\end{abstract}

Kata Kunci: koperasi, pemberdayaan masyarakat

\section{Empowering Garbage-Gathering Community in Citarum River through Bangkit Bersama Cooperation}

\begin{abstract}
This study aims to analyze the form of community empowerment conducted by Cooperative Bangkit Bersama by using the qualitative approach and in-depth interview method to 5 informants directly involved, explained to know and can provide information correctly related to the research focus undertaken. The findings of this study indicate that the people recognize the prosperity both economically and the sustainability of the around environment due to the reduced volume of waste, and water ecosystems that will gradually repair due to water hyacinth that is utilized by the community. The form of empowerment is done by raising awareness and providing training so that people have the abilities to cultivate their potential and can solve the problems they face.
\end{abstract}

Keywords: cooperative, community empowerment

How to Cite: Harahap, F. (2017). Pemberdayaan masyarakat pemulung sampah Sungai Citarum melalui koperasi bangkit bersama. JPPM (Jurnal Pendidikan dan Pemberdayaan Masyarakat), 4(2), 180-186. doi:http://dx.doi.org/10.21831/jppm.v4i2.15253

Permalink/DOI: http://dx.doi.org/10.21831/jppm.v4i2.15253 


\section{Jurnal Pendidikan dan Pemberdayaan Masyarakat, 4 (2), November 2017 - 180}

Friska Indria Nora Harahap

\section{PENDAHULUAN}

Indonesia merupakan salah satu negara berkembang yang memiliki beragam permasalahan salah satunya adalah kemiskinan. Menurut Badan Pusat Statistik (BPS) mencatat pada Maret 2017 jumlah penduduk miskin mencapai 27,77 juta orang atau sekitar 10,64 persen dari jumlah total penduduk Indonesia, dari angka tersebut bertambah sekitar 6,90 ribu orang penduduk miskin dibandingkan data 2016. Masalah kemiskinan selalu menjadi perhatian semua pihak untuk dipecahkan, penyebabnya juga bermacam-macam dan begitu juga dengan upaya menanggulanginya. Pada dasarnya kemiskinan selalu mengarah kepada tingkat kesejahteraan masyarakat yang rendah. Kemiskinan bukan hanya kekurangan kebutuhan utama (pokok) seperti sandang dan pangan saja, tetapi juga kebutuhan tambahan lainnya seperti pemukiman yang sehat, air bersih, kesehatan, sumber energi, pendidikan, transportasi, dan rekreasi. Di luar dari kebutuhan-kebutuhan pokok tersebut, ada kebutuhan yang paling dianggap penting oleh masyarakat yaitu kebutuhan akan mata pencaharian, karena dengan mempunyai mata pencaharian akan memudahkan akses masyarakat kepada pemenuhan kebutuhan pokoknya. Banyak upaya yang sudah dilakukan pemerintah untuk menanggulangi kemiskinan berupa bantuan modal maupun melalui program-program pemberdayaan masyarakat. Kebanyakan dari program-program yang ada dilapangan hanya fokus kepada pemberian modal tanpa memperhatikan aspek lain yang penting untuk di bangun atau biasnya pemberdayaan dengan menggunakan pendekatan top down. Ada juga pemberdayaan yang memang real berasal dari masyarakat atau karena inisiatif masyarakat itu sendiri yaitu pemberdayaan yang sering disebut dengan pendekatan bottom up. Koperasi Bangkit Bersama adalah salah satu lembaga yang melakukan pemberdayaan dengan pendekatan bottom up yang bertujuan mensejahterakan masyarakat dengan mengoptimalkan kemampuan yang dimiliki oleh masyarakat dan memanfaatkan potensi sumber daya alam maupun peluangpeluang usaha yang dapat diciptakan oleh masyarakat itu sendiri untuk keluar dari permasalahan perekonomian maupun permasalah lingkungan yang dihadapi. Seperti yang termuat dalam Undang-Undang No. 25 Tahun 1992 pasal 4 yang mengatakan bahwa fungsi dan peran koperasi salah satunya adalah membangun dan mengembangkan potensi dan kemampuan ekonomi anggota pada khususnya dan masyarakat pada umumnya untuk meningkatkan kesejahteraan ekonomi dan sosialnya.

Koperasi Bangkit Bersama termasuk kedalam salah satu lembaga koperasi yang memberikan kemudahan-kemudahan dalam hal pinjaman modal usaha, pengobatan gratis, peyediaan warung serba ada yang dikelola oleh anggota koperasi dan pemberian pinjaman biaya pendidika yang dapat dicicil oleh angggota koperasi. Sama halnya dengan pernyataan yang dingkapkan oleh Hermanik (2010) yang mengatakan bahwa salah satu upaya yang dilakukan oleh masyarakat untuk memberdayakan perempuan terkait dengan kesulitan memperoleh akses atas sumber keuangan mereka adalah dengan memberdayakan perempuan melalui koperasi. Dalam hal ini tidak hanya kaum perempuan saja yang diberdayakan oleh pihak koperasi tetapi mencakup masyarakat pada umumnya.

Upaya yang paling awal yang dapat dilakukan untuk menanggulangi kamiskinan adalah dengan memberikan penyadaran akan permasalahan dan solusi yang akan mereka dapatkan. Sama halnya dengan pendapat Wrihatnolo \& Dwidjowijoto (2007) yang mengatakan bahwa tahapan dari proses pemberdayaan yang pertama adalah penyadaran yang memuat sosialisasi terhadap komunitas agar mereka mengerti bahwa kegiatan pemberdayaan ini penting bagi peningkatan kualitas hidup mereka, dan dilakukan secara mandiri (self-help). Mengelola masyarakat untuk memiliki motivasi untuk merubah dan memperbaiki pola hidupnya menjadi masyarakat sejahtera (Riyani, Suherma, \& Nizar, 2010). Selain motivasi, inisiatif juga harus dimiliki oleh masyarakat sebagai salah satu ciri dari masyarakat berdaya. Pemberdayaan yang dilakukan oleh Koperasi Bangkit Bersama yang ada di Kampung Babakan Cianjur Desa 


\section{Jurnal Pendidikan dan Pemberdayaan Masyarakat, 4 (2), November 2017 - 181}

Friska Indria Nora Harahap

Cihampelas Kabupaten Bandung Barat ini merupakan salah satu pemberdayaan yang baik. Karena sesuai dengan kebutuhan dan permasalahan masyarakat. Permasalahan tumpukan sampah plastik, gulma eceng gondok yang dianggap selama ini sebagai masalah besar telah berubah menjadi mata pencaharian untuk masyarakat. Koperasi dengan gagasan membangun simbiosis mutualisme antara pemberdayaan masyarakat disekitar waduk dengan upaya peningkatan pendapatan dan pelestarian lingkungan yang beranggotakan warga masyarakat yang berprofesi pemulung dan masyarakat miskin yang bermukim di sekitar waduk Saguling. Berangkat dari realitas sebagaimana disebutkan, penelitian ini difokuskan pada menganalisis bentuk pemberdayaan masyarakat yang dilakukan melalui Koperasi Bangkit Bersama Babakan Cianjur.

\section{METODE}

Penelitian ini menggunakan pendekatan kualitatif. Pendekatan kualitatif menghasilkan data deskriptif berupa kata-kata tertulis dan lisan dari orang-orang dan perilaku yang diamati. Creswell (2016, p. 4) mengemukakan bahwa pendekatan kualitatif bertujuan untuk mengeksplorasi dan memahami sejumlah individu atau sekelompok orang yang dianggap berasal dari masalah sosial atau kemanusiaan. Pendapat tersebut sejalan dengan tujuan penelitian untuk menemukan dan menganalisis secara detail bentuk pemberdayaan masyarakat Pemulung Sampah bantaran waduk saguling melalui Koperasi Bangkit Bersama yang dijelaskan dengan kata-kata bukan dengan angka-angka. Dalam penelitian kualitatif tidak menggunakan istilah populasi tetapi narasumber, partisipan atau informan. Menurut (Bungin, 2007, p. 76) informan penelitian adalah subjek yang memahami informasi obyek penelitian sebagai pelaku maupun orang lain yang memahami obyek penelitian. Berdasarkan hal tersebut sangatlah jelas bahwa yang menjadi sumber data atau subyek penelitian dalam penelitian ini sebanyak 5 orang yang terlibat langsung, memiliki pengetahuan, dapat mengemukakan, menjelaskan, menyatakan, mendemonstrasikan, dan memperlihatkan berbagai kegiatan berkenaan dengan fokus penelitian yang berhubungan dengan pemberdayaan masyarakat pemulung sampah bantaran Waduk Saguling.

\section{HASIL DAN PEMBAHASAN}

Koperasi Bangkit Bersama adalah koperasi yang didirikan pada tahun 2009 dan resmi sebagai koperasi yang berbadan hukum pada tahun 2011 dengan akta pendirian Notaris Yukasanu Santihapsari SH., M.Kn nomor 1 tanggal 1 Desember tahun 2011, dan disahkan oleh Kementrian Koperasi Usaha Kecil dan Menengah Republik Indonesia nomor: 120/BH/XIII.26/518-KOP/I/2012. Koperasi yang didirikan oleh Bapak Indra Darmawan, S.Si seorang lulusan matematika Unpad yang sangat prihatin terhadap keadaan masyarakat di sekitarnya. Masalah lingkungan dan ekonomi merupakan alasan dibalik dorongan terbentuknya Koperasi Bangkit Bersama ini. Rendahnya tingkat pendidikan dan tingginya angka putus sekolah yang disebabkan oleh rendahnya ekonomi masyarakat semakin membuktikan bahwa ekonomi sangat berperan penting dalam pendidikan dan begitu juga sebaliknya.

Koperasi adalah gerakan ekonomi rakyat maupun badan usaha yang berperan dalam mewujudkan masyarakat yang maju, adil dan makmur. Oleh karena itu Koperasi dapat dianggap sebagai salah satu strategi pemberdayaan untuk membantu masyarakat menyelesaikan permasalahan yang mereka hadapi, baik permasalahan ekonomi, sosial dan lingkungannya. Masyarakat diarahkan agar menjadi masyarakat mandiri, yaitu yang mampu menguasai atau berkuasa atas kehidupannya. Slamet (Anwas, 2013) mengatakan bahwa selain dapat berkuasa atas diri sendiri, setiap individu yang dikatakan mandiri atau berdaya adalah individu yang mampu membangun dirinya dan memperbaiki kehidupannya sendiri. Adapun bentuk upaya yang dilakukan Koperasi Bangkit Bersama dalam rangka memberikan daya dan power kepada masyarakat dengan mengubah prilaku masyarakat setempat. mengubah perilaku dengan meningkatkan kemampuan yang mereka miliki dengan memberikan penyadaran lebih awal dan kemudian mem- 


\section{Jurnal Pendidikan dan Pemberdayaan Masyarakat, 4 (2), November 2017 - 182}

Friska Indria Nora Harahap

berikan keterampilan melalui pelatihan yang diadakan oleh koperasi. Sama halnya dengan yang diungkapkan oleh Soero, Sulistyo, \& Hayat (2014) pemberdayaan tersebut dapat dikatakan sebagai salah satu bentuk pembangunan, karena pembangunan juga bertujuan untuk meningkatkan kemampuan manusia dalam mempengaruhi masa depannya. Setelah penyadaran, dan pemberian keterampilan dan bentuk yang terakhir yang dilakukan adalah memberikan bantuan pinjaman modal buat baik untuk membeli perahu untuk mengambil sampah di waduk maupun bantuan modal buat usaha dan untuk hidup sehari-hari.

Masyarakat di sekitaran Waduk Saguling adalah masyarakat yang mempunyai masalah dengan sampah sungai Citarum, angka putus sekolah, dan kemiskinan. Selain itu masyarakat bantaran waduk masih jauh dari kategori masyarakat berdaya, karena tidak hanya permasalahan sosial ekonomi, masyarakat juga tidak menyadari akan masalah mereka selama ini dan tidak mempunyai inisiatif untuk penyelesaiannya. Dengan berbagai masalah yang ada dibentuklah sebuah konsep pemberdayaan himpunanan matematika yang digagas oleh Bapak Indra sendiri selaku pendiri Koperasi yang tujuannya adalah mengatasi permasalah tersebut.

Koperasi sebagai gerakan ekonomi rakyat maupun sebagai badan usaha berperan serta untuk mewujudkan masyarakat yang maju, adil dan makmur Permasalahan sosial ekonomi seperti kemiskinan, kebodohan dan masyarakat yang tidak mempunyai keterampilan ataupun kecakapan. Permasalahan yang kedua adalah permasalahan kerusakan lingkungan yang ditimbulkan oleh sampah kiriman sungai citarum yang kian menggunung, gulma eceng gondok yang merusak ekosistem air dan lingkungan yang semakin rusak. Permasalahan ini dapat diselesaikan dengan pemberdayaan melalui koperasi Bangkit Bersama. Sejalan dengan pernyataan Kartasasmita (2007) yang mengatakan bahwa pemberdayaan masyarakat adalah sebuah konsep pembangunan ekonomi yang merangkum nilai-nilai sosial.
Sebelum membuat program-program pemberdayaan, hal yang paling pertama dilakukan adalah mengidentifikasi masalah dan kebutuhan masyarakat. Kemudian merumuskan solusi untuk setiap masalahmasalah yang diidentifikasi. Setiap unsur masyarakat harus dilibatkan, karena masyarakatlah adalah unsur yang akan dibebaskan dari segala ketidakberdayaannya. Menurut Freire (Anwas, 2013) pembebasan itu seharusnya dilakukan oleh kaum tertindas itu sendiri. Karena pada hakekatnya hanya masyarakat itu sendirilah yang paling mengetahui kemampuan dan kebutuhan dari mereka. Keberhasilan dari pemberdayaan itu adalah bukan hasil akhirnya tetapi seberapa banyak orang yang terlibat dalam prosesnya. Menurut Suharto (2010) pemberdayaan sebagai proses adalah serangkaian kegiatan untuk memperkuat kekuasaan atau keberdayaan kelompok lemah dalam masyarakat, termasuk individu-individu yang mengalami masalah kemiskinan. Kelompok lemah atau orang-orang yang tidak berdaya baik secara ekonomi, pendidikan, dll diberikan power oleh koperasi.

Koperasi Indonesia termasuk koperasi bangkit bersama bertidak bukan sekedar semata-mata untuk mencari laba sebesarbesarnya, atau sebagai badan usaha seperti firma, perseroan terbatas, tetapi lebih daripada itu semua, koperasi di Indonesia merupakan agen pembangunan untuk pengentasan kemiskinan, merupakan usaha pemberdayaan, meningkatkan kesejahteraan masyarakat, dan berperan untuk menyebarluaskan jiwa dan semangat koperasi untuk dapat dikembangkan pada perusahaan swasta dan Negara. Dan dipertegas oleh Muis (2009) bahwa Koperasi di Indonesia lebih kepada mencari bagaimana dengan diadakannya perkumpulan dapat memberikan kesejahteraan, kemakmuran, kekompakan kepada setiap anggotanya. Jadi keuntungan dapat dirasakan secara bersama, kolektif, tidak dirasakan oleh segelintir orang saja.

Sesuai dengan peran koperasi yang sebenarnya, koperasi Bangkit bersama telah melakukan perannya sebagai salah satu strategi pemberdayaan, dimana koperasi sebagai pemberi power atau kekuatan dan masyarakat yang menjadi pihak-pihak yang akan 


\section{Jurnal Pendidikan dan Pemberdayaan Masyarakat, 4 (2), November 2017 - 183}

Friska Indria Nora Harahap

diberi kekuatan atau yang akan diberdayakan. Bantuan yang diberikan koperasi berupa bantuan unit perahu untuk mengambil sampah agar lebih banyak, karena dengan perahu dapat mengangkut sampah lebih banyak dan otomatis penghasilan pun semakin banyak. Tidak hanya sampai disitu, dengan bantuan perahu para pemulung tidak hanya mengambil sampah dari bantaran sungai saja tetapi bisa sampai ketengah-tengah sungai untuk mengambil sampah. Selain koperasi bisa memberikan pinjaman uang kepada anggotanya, pembayarannya untuk setiap pinjaman dapat berupa sampah, anggota koperasi juga diberikan pelatihan membuat kerajinan dari bahan eceng gondok yang dapat merusak ekosostem air. Keuntungan ekonomi yang diperoleh masyarakat untuk meningkatkan taraf hidup yang lebih baik, ternyata masyarakat juga mendapatkan pengetahua dan keterampilan pengolahan eceng gondok untuk berbagai produk, berupa briket, kerajinan eceng gondok, media tanam eceng gondok dan daur ulang sampah baik organic dan anorganik. Selain untuk meningkatkan taraf ekonomi masyarakat strategi pemberdayaan berbasis pelestarian lingkungan juga menjadi dasar dari konsep pemberdayaan yang dilakukan oleh koperasi bangkit bersama.

Keprihatinan yang ditemui bukan hanya masalah lingkungan dengan sampah yang semakin menggunung yang berakibat kepada terganggunya kesehatan masyarakat tetapi sangat erat kaitannya dengan bencana alam yang akan ditimbulkan oleh tumpukan sampah tersebut. selain masalah lingkungan masalah sosial dan ekonomi juga tidak terlepas dari masyarakat disekitar bantara waduk saguling. Pengangguran dan angka putus sekolah menjadi hal biasa bagi masyarakat setempat.

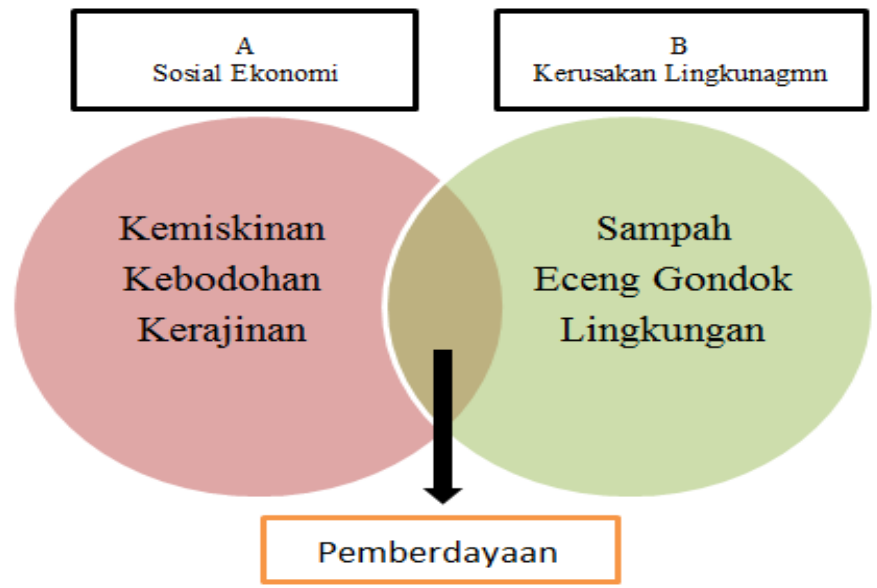

Gambar 1. Kaitan Himpunan Matematika dan Konsep Pemberdayaan masyarakat (Sumber: Hasil Wawancara dengan Bapak Indra Darmawan)

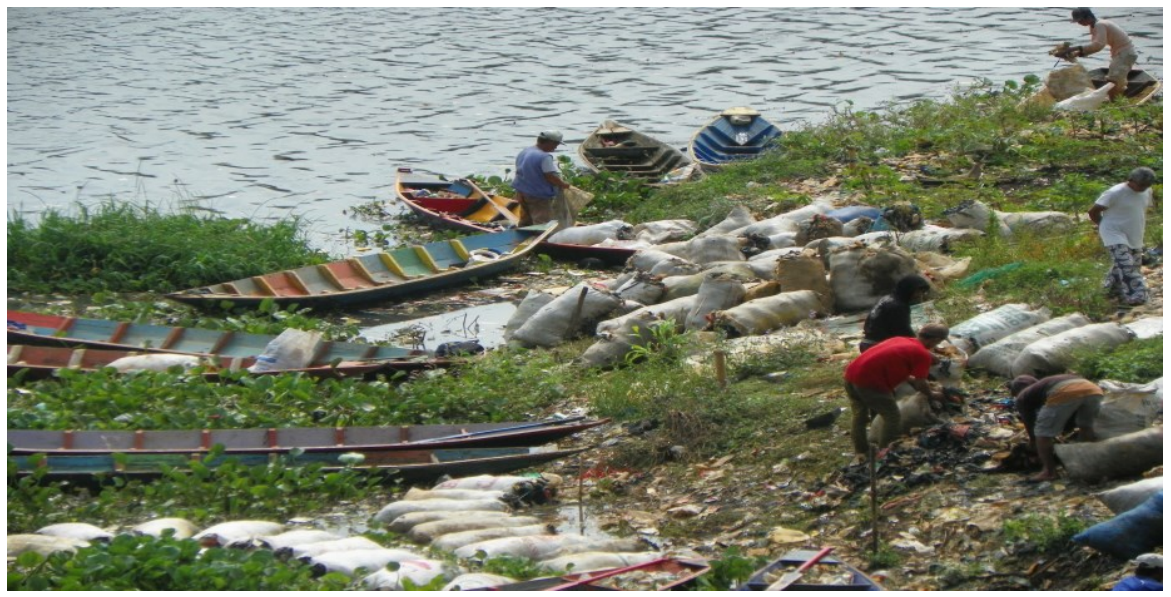

Gambar 2. Kegiatan Masyarakat Pemulung Sampah Bantaran Sungai setelah Mendapatkan Perahu (Sumber Dokumentasi Pribadi Koperasi Bangkit Bersama) 


\section{Jurnal Pendidikan dan Pemberdayaan Masyarakat, 4 (2), November 2017 - 185 \\ Friska Indria Nora Harahap}

Koperasi bangkit bersama adalah satu bentuk dari pemberdayaan masyarakat. Yang bertujuan menjadi lembaga ekonomi masyarakat yang terbuka dan transparan yang mampu meningkatkan harkat dan martabat kehidupan masyarakat secara luas dengan tetap berpijak pada pelestarian lingkungan. Dari tujuan tersebut diketahui koperasi bangkit bersama ingin memampukan masyarakat

\section{SIMPULAN}

Pemberdayaan yang dilakukan oleh Koperasi Bangkit Bersama merupakan jenis usaha sadar yang dilakukan oleh masyarakat setempat untuk mengatasi keterbelakangan atau kesusahan yang mereka hadapi. Dengan menggunakan pendekatan bottom up pemberdayaan yang dilakukan oleh koperasi selalu bertumpu kepada kebutuhan dan berdasarkan permasalahan yang sedang dihadapi oleh masyarakat, karena bagi koperasi Bangkit Bersama konsep pemberdayaan mereka adalah masyarakat harus sebagai subjek dan objek dari pemberdayaan itu sendiri karena pemberdayaan yang berasal dari masyarakat, oleh masyarakat dan untuk masyarakat.Walaupun pemberdayaan dengan pendekatan bottom up dianggap sangat membutuhkan waktu yang relative lama dibandingkan dengan pendekatan top down, tetapi hasil dari pendekatan bottom up dianggap lestari atau dapat bertahan lama dimasyarakat karena inisiatif pemberdayaan berasal dari masyarakat itu sendiri.

Pemberdayaan yang menggunakan koperasi sebagai salah satu strategi pemberdayaannya tidak hanya sebatas untuk mengejar atau bertujuan untuk pemenuhan dalam meningkatkat taraf ekonomi saja, tetapi pemberdayaan yang dilakukan oleh Koperasi Bangkit Bersama juga menjadikan Pelestarian Lingkungan sebagai basis dari pemberdayaan mereka. Karena pemberdayaan yang sesungguhnya adalah memampukan masyarakat dengan mengoptimalkan kemampuan yang masyarakat miliki tanpa harus ada yang harus dirusak.

\section{ACKNOWLEDGEMENT}

Terimakasih disampaikan kepada semua pihak di Koperasi Bangkit Bersama yang telah memberikan informasi secara lengkap terkait penelitian ini.

\section{DAFTAR PUSTAKA}

Anwas, O. M. (2013). Pemberdayaan masyarakat di era global. Bandung: Alfabeta.

Bungin, B. (2007). Penelitian kualitatif: Komunikasi, ekonomi, kebijakan publik, dan ilmu sosial lainnya. Jakarta: Kencana.

Creswell, J. W. (2016). Research design: pendekatan kualitatif, kuantitatif, dan mixed. Yogyakarta: Pustaka Pelajar.

Hermanik, E. (2010). Perempuan dan koperasi (Studi model pemberdayaan perempuan melalui KWSU Setia Budi Wanita Malang). Muwazah: Jurnal Kajian Gender, 2(2). Retrieved from http://e-journal.stainpekalongan.ac.id/index.php/Muwazah /article/view/332

Kartasasmita, G. (2007). Revitalisasi administrasi publik dalam mewujudkan pembangunan berkelanjutan. Makalah Yang Disampaikan Pada Acara Wisuda Ke44 Sekolah Tinggi Administrasi Lembaga Administrasi Negara, Jakarta. Jakarta: h Tinggi Administrasi Lembaga Administrasi Negara.

Muis, A. (2009). Mengenal koperasi dan perkembangannya di Indonesia. Jurnal Fisip: Madani, 9(1).

Riyani, Y., Suherma, L., \& Nizar, N. (2010). Analisis pengaruh program pengentasan kemiskinan dalam upaya menghasilkan suatu model pengentasan kemiskinan yang berkelanjutan (Studi eksperimen pada Dusun Wonodadi Desa Sei. Bulan Kabupaten Kubu Raya Provinsi Kalimantan Barat). Jurnal Aplikasi Manajemen, 8(2), 318-324. Retrieved from

http://jurnaljam.ub.ac.id/index.php/ja $\mathrm{m} /$ article/view/330

Soero, P. M. H. P., Sulistyo, D., \& Hayat, A. (2014). Pemberdayaan istri nelayan 
Jurnal Pendidikan dan Pemberdayaan Masyarakat, 4 (2), November 2017 - 186

Friska Indria Nora Harahap

melalui koperasi unit desa (KUD) (Studi pada KUD Mina Jaya Sendang Biru Kecamatan Sumbermanjing Wetan Kabupaten Malang). Jurnal Administrasi Publik, 2(1), 41-46. Retrieved from http://administrasipublik.studentjourn al.ub.ac.id/index.php/jap/article/view/ 337
Suharto, E. (2010). Membangun masyarakat memberdayakan rakyat. Bandung.

Wrihatnolo, R. R., \& Dwidjowijoto, R. N. (2007). Manajemen pemberdayaan: Sebuah pengantar dan panduan untuk pemberdayaan masyarakat. Jakarta: PT Elex Media Komputindo. 